\title{
OPTIMASI VARIABEL YANG PALING BERPENGARUH PADA PEMBUATAN BIODIESEL DARI MINYAK BIJI RANDU DENGAN PROSES TRANSESTERIFIKASI
}

\author{
Mudzofar Sofyan*), Ilham Tanjung, Herry Santosa \\ Jurusan Teknik Kimia, Fakultas Teknik, Universitas Diponegoro, \\ Jl. Prof. Soedarto, SH, Kampus Undip Tembalang, Semarang, Indonesia 50275
}

\begin{abstract}
Abstrak
Biodiesel merupakan salah satu bahan bakar alternatif pengganti solar yang dibuat dari sumber yang dapat diperbaharui seperti minyak nabati dan lemak hewani. Salah satu bahan alami yang dapat digunakan sebagai material dalam pembuatan biodisel adalah biji randu. Keberadaan bahan baku yang cukup melimpah merupakan kesempatan besar untuk bisa dikembangkan menjadi pilihan energi alternatif yang dikembangkan dalam skala komersial. Biodiesel dari minyak biji randu dapat dibuat melalui reaksi transesterifikasi dua tahap yang dibantu dengan menggunakan katalis basa. Penelitian ini bertujuan untuk mengkarakterisasi minyak biji randu, menentukan variabel yang paling berpengaruh antara suhu, waktu, dan rasio minyak-metanol terhadap yield yang dihasilkan melalui metode factorial design, optimasi variabel yang paling berpengaruh terhadap yield yang dihasilkan, dan mengkarakterisasi biodiesel yang dihasilkan. Proses transesterifikasi dua tahap menggunakan KOH sebagai katalis dengan variabel berubah, yaitu: suhu, rasio methanol-minyak, dan waktu. Dari hasil penelitian didapatkan bahwa minyak biji randu memiliki kadar FFA sebesar 17,97\% dan bilangan penyabunan sebesar 172,55 $\mathrm{mgKOH} / \mathrm{g}$. Variabel yang paling berpengaruh yaitu variabel waktu. Pada optimasi variabel waktu, didapatkan secara optimal pada waktu 105 menit dengan perolehan yield sebesar 77,39\%. Hasil karakterisasi produk biodiesel menunjukkan dari tujuh parameter pengujian, empat parameter sesuai dengan standar yang disyaratkan SNI.
\end{abstract}

Kata kunci: minyak biji randu; biodiesel; transeterifikasi; waktu

\begin{abstract}
[Biodiesel Production from Kapok Seed Oil with KOH Catalyst Using Two Steps Transesterification Process] Biodiesel is one of diesel fuel alternative made from renewable resources such as vegetable oils and animal fats. One of the natural ingredients that can be used as a material in the production of biodiesel is kapok seed. The existence of relatively abundant raw materials is a great opportunity to be developed into alternative energy options which developed on a commercial scale. Biodiesel from kapok seed oil can be made through a two-stage transesterification reaction which helped by using a base catalyst. This research aims to characterize the kapok seed oil, determine the most influential variables between temperature, the ratio of methanol-oil, and time against yield by the factorial design method, optimization variables that most influence on yield, and characterize the biodiesel. Two-stage transesterification process using $\mathrm{KOH}$ as the catalyst with changing variables: temperature, methanol-oil ratio, and time. The result showed that kapok seed oil has FFA content: 17.97\% and a saponification number: $172.55 \mathrm{mgKOH} / \mathrm{g}$. Most influential variable is the variable of time. At the variable optimization of time, the result were optimally obtained at the 105th minutes with yield: $77.39 \%$. The characterization results of biodiesel's product show from seven parameters of testing, four parameters are required in accordance with SNI.
\end{abstract}

Keywords: kapok seed oil; biodiesel; transesterification; time

\section{Pendahuluan}

Meskipun produksi dari segi jumlah minyak mentah Indonesia sanggup untuk memenuhi kebutuhan dalam negeri, impor minyak solar harus

\footnotetext{
${ }^{*}$ Penulis Korespondensi.

E-mail: mudzofars@gmail.com
}

dilakukan karena kapasitas kilang minyak yang tersedia tidak mencukupi untuk memenuhi seluruh permintaan solar dalam negeri. Di masa mendatang, kebutuhan akan minyak solar dipastikan terus meningkat seiring dengan pertumbuhan penduduk dan volume kegiatan ekonomi (Widyawati, 2007).

Biodiesel merupakan salah satu bahan bakar alternatif pengganti solar yang dibuat dari sumber 


\section{Teknik, 35 (1), 2014, 43}

yang dapat diperbaharui seperti minyak nabati dan lemak hewani. Dibandingkan bahan bakar fosil, biodiesel mempunyai kelebihan diantaranya bersifat biodegradable, non-toxic, mempunyai angka emisi dan gas sulfur yang rendah, serta sangat ramah terhadap lingkungan (Marchetti dan Errazu, 2008).

Salah satu bahan alami yang dapat digunakan sebagai bahan baku dalam pembuatan biodisel adalah biji randu. Biji randu mengandung 24\%-40\% minyak, sehingga sangat berpotensi untuk dikembangkan menjadi produk biodisel (Soerawidjaja, 2005). Minyak biji randu tergolong minyak non-pangan (non-edibel oil) sehingga bila digunakan sebagai bahan baku alternatif pengganti migas tidak akan mengurangi pasokan minyak pangan di Indonesia (Dewajani, 2008). Minyak biji randu memiliki banyak keunggulan: mudah didapat, harganya relatif murah, kadar asam lemak tak jenuhnya tinggi (71.95\%), dan bilangan iodine yang memenuhi standar spesifikasi biodiesel (88 g/g) (Hambali, 2006; Prihandana dkk., 2006). Setiap gelendong buah randu mengandung $26 \%$ biji buah randu sehingga tiap $100 \mathrm{~kg}$ gelendongnya bisa menghasilkan $26 \mathrm{~kg}$ biji randu (Dewajani, 2008). Biodiesel dari minyak biji randu memiliki angka iodine yang tinggi. Semakin tinggi bilangan iodine, maka titik tuang (pour point) minyak biji randu menjadi semakin rendah. Keadaan terbebut menjadikan biodiesel dari bahan baku minyak biji randu diminati oleh negara-negara bermusim dingin, sehingga biodiesel dari minyak biji randu dapat dijadikan komoditas ekspor yang potensial (Dewajani, 2008).

Keberadaan bahan baku yang cukup melimpah merupakan kesempatan besar untuk bisa dikembangkan menjadi pilihan energi alternatif yang dikembangkan dalam skala komersial. Di Kabupaten Pasuruan terdapat perkebunan kapuk randu sejumlah 12.604 hektar, dengan jumlah mencapai 2.048.757 pohon. Produksi kapuk dapat mencapai 4.170 ribu ton dan dapat menghasilkan lebih dari 7900 ton biji randu. Minyak biji randu selama ini hanya digunakan sebagai bahan baku alat penerangan, minyak pelumas, campuran coating pada genting, campuran pada kain batik, serta sumber protein untuk sapi dan domba.

Biodiesel dari minyak biji randu dapat dibuat melalui reaksi transesterifikasi yang dibantu dengan menggunakan katalis basa. Katalis basa yang umum digunakan adalah $\mathrm{NaOH}, \mathrm{KOH}$, karbonat dan alkoksida dari natrium dan kalium seperti natrium metoksida, etoksida, propoksida dan butoksida (Khan, 2002). Penelitian awal tentang biodiesel dengan bahan baku minyak biji randu menggunakan katalis $\mathrm{NaOH}$ menyimpulkan bahwa pembuatan biodiesel optimal pada suhu $40{ }^{\circ} \mathrm{C}$ (Dewajani, 2008). Pemakaian katalis $\mathrm{KOH}$ pada reaksi transesterifikasi telah berhasil pada berbagai jenis minyak, antara lain minyak biji kanola (Dmytryshyn dkk., 2004), minyak biji rami (linseed), minyak rapeseed (Lang dkk., 2001), minyak kelapa sawit (Darnoko dan Cheryan, 2000), minyak zaitun dan minyak kelapa sawit bekas (Dorado dkk., 2002) dan minyak jarak pagar (Foidl dkk., 1996). Katalis $\mathrm{KOH}$ juga dipilih karena harganya lebih murah dari $\mathrm{NaOH}$. Darnoko dan Cheryan (2000) merekomendasikan penggunaan katalis dengan konsentrasi yang lebih tinggi dari $1 \%$.

Beberapa penelitian melaporkan reaksi transesterifikasi yang dilangsungkan pada beberapa suhu. Semakin tinggi suhu reaksi, konstanta laju reaksi semakin meningkat. Peningkatan konstanta laju reaksi pembentukan produk lebih besar dari konstanta laju reaksi balik (Noureddini dkk., 1997). Suhu optimal reaksi transesterifikasi dilaporkan oleh Sumangat dkk. (2008) sebesar $30{ }^{0} \mathrm{C}$. Suhu maksimum untuk reaksi transesterifikasi adalah $65{ }^{\circ} \mathrm{C}$, di bawah titik didih metanol $68{ }^{\circ} \mathrm{C}$ (Darnoko dan Cheryan, 2000). Kemudian perbandingan mol metanol-minyak yang digunakan bervariasi seperti pada Susilowati (2006) dan Sumangat dkk. (2008) menggunakan rasio 6:1, sementara Santoso dkk. (2012) menggunakan rasio 15:1. Santoso dkk. (2012) juga menggunakan waktu reaksi dari 1 jam dan 2 jam, sedangkan Dewajani (2008) menggunakan waktu dari 30 menit hingga 120 menit dengan interval waktu 30 menit. Kemudian reaksi transesterifikasi dengan menggunakan katalis basa dapat dilakukan dalam satu tahap atau dua tahap (Sumangat dkk., 2008). Hasil penelitian Dorado dkk.(2002) melaporkan, transesterifikasi dua tahap pada minyak nabati memiliki tingkat konversi yang sedikit lebih tinggi dibandingkan transesterifikasi satu tahap. Konversi metil ester pada proses satu tahap berkisar $83-91 \%$, sementara pada proses dua tahap mencapai 87-95\% (Sumangat dkk., 2008). Dari beberapa indikasi di atas, maka perlu untuk dilakukan penelitian mengenai variabel optimal dari pembuatan biodiesel dari minyak biji randu menggunakan katalis $\mathrm{KOH}$ menggunakan proses transesterifikasi dua tahap. Beberapa variabel penting yang harus dioptimalisasi adalah variabel suhu, waktu, dan rasio pereaktan.

Artikel ini mengkaji karakterisasi minyak biji radu; menentukan variabel yang paling berpengaruh antara suhu, waktu, dan rasio minyak-metanol terhadap yield yang dihasilkan melalui metode factorial desing; optimasi variabel yang paling berpengaruh terhadap yield yang dihasilkan; dan karakterisasi biodiesel yang dihasilkan.

\section{Bahan dan Metode Penelitian \\ 2.1. Bahan dan Alat}

Bahan utama yang digunakan adalah minyak biji randu yang diperoleh dari Pati, Jawa Tengah dengan wujud cair, dan berwarna kuning. Bahan kimia yang digunakan adalah $\mathrm{KOH}$ teknis dengan wujud padatan dan berwarna putih, methanol 96\% dengan wujud cair dan tidak berwarna, $\mathrm{H}_{3} \mathrm{PO}_{4}$ p.a dengan wujud cair dan berwarna bening kekuningan, $\mathrm{H}_{2} \mathrm{SO}_{4}$ $97 \%$ dengan wujud cair dan berwarna bening kekuningan yang masing-masing diperoleh di toko bahan kimia Indrasari, Semarang dan akuades. Sedangkan alat yang digunakan meliputi reaktor 


\section{Teknik, 35 (1), 2014, 44}

transesterifikasi, neraca analitik, termometer, pendingin balik, oven, dan corong pemisah.

\subsection{Metode Penelitian}

Untuk menjawab tujuan, penelitian dilakukan melalui lima tahap, (1) Tahap karakterisasi minyak biji randu, (2) Tahap degumming, (3) Tahap esterifikasi, (4) Tahap transesterifikasi dua tahap, dan (5) Tahap karakerisasi biodiesel yang dihasilkan.

\subsubsection{Karakterisasi Minyak Biji Randu}

Tahap karakterisasi minyak biji randu dilakukan untuk mengetahui kadar gum, asam lemak bebas (berdasarkan angka asam), dan angka sabun sehingga dapat ditentukan kegiatan apa saja yang harus dilakukan terhadap minyak biji randu sebelum transesterifikasi dilakukan. Analisis bilangan asam digunakan untuk mengetahui kadar asam lemak bebas yang terkandung dalam minyak. Analisis bilangan penyabunan digunakan untuk menghitung kebutuhan metanol minimal sesuai stoikiometri reaksi transesterifikasi. Sedangkan analisis gum untuk mengetahui kadar gum atau getah dalam minyak biji randu. Analisis bilangan asam dilakukan dengan menggunakan metode AOCS Cd 3d-63 (Acid value of fats and oiles). Sedangkan analisis bilangan penyabunan menggunakan metode AOCS Cd 3-25 (Saponification value of oils and fats).

\subsubsection{Degumming}

Tahap ini dimaksudkan untuk menghilangkan gum pada minyak biji randu yang tidak bisa dihindari keberadaannya. Sedangkan keberadaan gum pada minyak biji randu ini tidak diinginkan karena mengakibatkan meningkatnya nilai viskositas kinematik biodiesel sehingga kualitas biodiesel yang dihasilkan menjadi kurang baik.

\subsubsection{Esterifikasi}

Tahap esterifikasi dimaksudkan untuk menurunkan kadar asam lemak bebas dengan mereaksikannya bersama metanol dengan bantuan katalis asam, hingga kadar asam lemak bebas minyak biji randu menjadi kurang dari $2 \%$.

\subsubsection{Transesterifikasi Dua Tahap}

Tahap transesterifikasi dua tahap dilakukan untuk menentukan variabel yang paling berpengaruh terhadap perolehan yield dan mengoptimasi variabel tersebut untuk mendapatkan kondisi operasi yang optimal. Tabel 1 merupakan rancangan percobaan untuk tahap traneserifikasi 2 tahap. Rancangan penelitian untuk mengetahui kondisi optimum untuk proses transesterifikasi menggunakan variabel tetap: $\mathrm{KOH}$ dan variabel yang kurang berpengaruh dan variabel berubah: variabel yang paling berpengaruh.

\subsubsection{Karakterisasi Biodiesel}

Tahap karakterisasi biodiesel dimaksudkan untuk mengetahui kualitas biodiesel yang dihasilkan dengan melakukan beberapa analisis yang disesuaikan dengan parameter SNI. Analisis yang dilakukan antara lain analisis mengenai densitas, viskositas kinematik, cetane number, titik kabut, bilangan asam, bilangan iodium, dan kadar alkil ester. Analisis yang dilakukan antara lain analisis mengenai densitas, viskositas kinematik, cetane number, titik kabut, bilangan asam, bilangan iodium, dan kadar alkil ester. Pengujian massa jenis menggunakan metode SNI 06-4085-1996, viskositas menggunakan metode ASTM D 445-04, Angka Setana menggunakan metode Azam dkk. (2005), Titik Kabut metode Ana (2006), Angka Asam metode SNI 01-3555-1998, Angka iodium metode SNI 01-3555-1998, dan Kadar Alkil Ester menggunakan metode SNI 04-7182-2006.

Tabel 1. Transesterifikasi dua tahap dengan tariabel tetap: katalis $\mathrm{KOH}$, dan variabel berubah: suhu $(\mathrm{T})=$ $35,65{ }^{\circ} \mathrm{C}$, waktu (t) $=30,120$ menit, dan rasio pereaktan $(\mathrm{R})=(6: 1,15: 1)$

\begin{tabular}{cccccc}
\hline \multirow{2}{*}{ No } & \multicolumn{3}{c}{ Variabel } & & Respon \\
\cline { 2 - 4 } \cline { 5 - 6 } & $\mathrm{T}\left({ }^{\circ} \mathrm{C}\right)$ & $\mathrm{T}($ menit $)$ & $\mathrm{R}$ & & Yield (\%) \\
\hline 1 & 35 & 30 & $6: 1$ & & $\sqrt{ }$ \\
2 & 65 & 30 & $6: 1$ & & $\sqrt{ }$ \\
3 & 35 & 120 & $6: 1$ & & $\sqrt{ }$ \\
4 & 65 & 120 & $6: 1$ & & $\sqrt{ }$ \\
5 & 35 & 30 & $15: 1$ & & $\sqrt{ }$ \\
6 & 65 & 30 & $15: 1$ & & $\sqrt{ }$ \\
7 & 35 & 120 & $15: 1$ & & $\sqrt{ }$ \\
8 & 65 & 120 & $15: 1$ & & $\sqrt{ }$ \\
\hline
\end{tabular}

\section{Hasil dan Pembahasan}

\subsection{Karakterisasi Minyak Biji Randu}

Tahap karakterisasi dimaksudkan untuk mengetahui tahap yang harus dilakukan dalam pembuatan biodiesel dari minyak biji randu. Lebih lanjut, tahap karakterisasi ini dilakukan untuk menganalisis bilangan asam, bilangan penyabunan dan gum. Analisis bilangan asam digunakan untuk mengetahui kadar asam lemak bebas yang terkandung dalam minyak. Analisis bilangan penyabunan digunakan untuk menghitung kebutuhan metanol minimal sesuai stoikiometri reaksi transesterifikasi. Sedangkan analisis gum untuk mengetahui kadar gum atau getah dalam minyak biji randu.

Tabel 1. Hasil karakterisasi minyak biji randu

\begin{tabular}{cc}
\hline Parameter & Nilai \\
\hline Bilangan Asam $(\mathrm{mg}$ & 35,952 \\
$\begin{array}{c}\mathrm{KOH} / \mathrm{g}) \\
\text { Bilangan Penyabunan } \\
(\mathrm{mg} \mathrm{KOH} / \mathrm{g})\end{array}$ & 172,55 \\
\hline
\end{tabular}

Dari hasil analisis yang disajikan dalam Tabel 2, kadar asam lemak bebas (FFA) yang terdapat dalam minyak biji randu tergolong cukup tinggi yaitu $17,97 \%$. Adanya asam lemak bebas dalam minyak akan mengganggu proses transesterifikasi dan akan terjadi reaksi penyabunan antara asam dengan katalis basa, sehingga asam lemak bebas perlu dihilangkan atau setidaknya dikurangi hingga dibawah $2 \%$. Asam 


\section{Teknik, 35 (1), 2014, 45}

lemak bebas yang terdapat dalam minyak dapat dihilangkan dengan cara esterifikasi. Esterifikasi merupakan reaksi antara asam lemak bebas dengan metanol membentuk biodiesel dan air. Setelah esterifikasi dilakukan, asam lemak bebas berkurang hingga $0,705 \%$. Bilangan penyabunan yang diperoleh sebesar $172,55 \mathrm{mg} \mathrm{KOH} / \mathrm{g}$ sehingga untuk berat minyak sebesar 200 gram, dibutuhkan minimal 23,36 $\mathrm{ml}$ metanol untuk bisa bereaksi dengan trigliserida.

Banyak penelitian menyebutkan bahwa semua minyak nabati mengandung gum atau getah sehingga analisis kadar gum tidak harus dilakukan. Sedangkan, adanya gum dalam minyak tidak diinginkan karena akan menimbulkan emulsi sabun dan akan mengganggu proses pemurnian (Erricson, 1990). Selain itu, dengan adanya gum yang berlebihan akan meningkatkan nilai viskositas kinematik biodiesel sehingga kualitas biodiesel yang dihasilkan menjadi kurang baik. Oleh karena itu, usaha untuk mengurangi kadar gum harus dilakukan yaitu dengan degumming.

\subsection{Penentuan Variabel yang Paling Berpengaruh}

Transesterifikasi telah dilakukan sesuai dengan variabel operasi yang telah ditentukan dan divariasikan melalui metode faktorial desain. Tabel 3 menunjukkan hasil perolehan yield tiap percobaan dan hasil olah data perhitungan efek dari tiap variabel. Perhitungan efek atau pengaruh setiap variabel dihitung menggunakan Metode Quicker.

Yield adalah perbandingan jumlah produk dengan jumlah bahan baku awal. Dengan demikian yield bisa dirumuskan sebagai berikut:

$$
\text { Yield }=\frac{\text { Volume akhir perolehan biodiesel }}{\text { Volume awal minyak }} \times 100 \%
$$

Dari perhitungan efek Tabel 3 dapat diketahui variabel yang paling berpengaruh adalah variabel waktu (t). Hal ini menunjukkan bahwa waktu perlu dijadikan variabel yang lebih banyak divariasikan rentangnya. Maka dari itu, optimasi variabel dilakukan dengan memvariasikan variabel waktu dengan rentang tertentu untuk mengetahui pada waktu berapa yield yang diperoleh maksimal.
Setiap variabel pada setiap kombinasi percobaan mempunyai pengaruh yang berbeda terhadap hasil volume biodiesel yang didapat. Ketiga variabel antara suhu, waktu, dan rasio metanolminyak, saling mempengaruhi sehingga menghasilkan yield yang bervariasi di setiap percobaan. Hanya ketika dihitung pengaruhnya terhadap besarnya yield waktu menunjukkan variabel yang paling berpengaruh.

\section{Pengaruh Suhu}

Suhu yang digunakan dalam reaksi transesterifikasi ini terdiri dari dua level yaitu $35{ }^{\circ} \mathrm{C}$ dan $65{ }^{\circ} \mathrm{C}$. Fenomena pengaruh suhu terhadap yield yang diperoleh dapat diamati dari $\Delta$ Yield. Pada Tabel 4 , poin 2 dan 4 terjadi penurunan yang sangat drastis, dimana dua poin ini berada pada waktu 120 menit. Sedangkan poin 1 dan 3, yang mengalami kenaikan yield, berada pada waktu 30 menit. Selain itu, jika dilihat dari besar $\Delta$ Yield, maka poin 1 dan 2 memiliki $\Delta$ Yield yang lebih kecil dibandingkan poin 3 dan 4 , hal ini merupakan pengaruh penggunaan rasio metanol-minyak yang berbeda. Beberapa fenomena tersebut merupakan bukti saling mempengaruhinya variabel yang satu dengan yang lain sehingga zmenghasilkan fenomena yang berbeda-beda.

Pengaruh suhu yang meningkat terhadap menurunnya yield dijelaskan juga dalam beberapa penelitian. Sumangat dan Hidayat (2008) menyebutkan bahwa pada perlakuan suhu tinggi, terdapat indikasi terjadi reaksi oksidasi termal, yaitu dekomposisi susunan kimiawi akibat pengaruh panas. Reaksi oksidasi ini dapat terjadi selama proses pemanasan minyak sebelum metanol ditambahkan. Reaksi ini juga dapat terjadi pada metil ester saat reaksi transesterifikasi berlangsung. Peristiwa oksidasi ini menyebabkan terbentuknya molekul hidroperoksida, aldehida, keton dan asam yang dapat mengubah sifat bahan bakar. Senyawa hidroperoksida memicu terjadinya polimerisasi dan mengakibatkan terbentuknya endapan yang tidak larut. Endapan tidak larut inilah yang tereliminasi dalam proses pemisahan, sehingga volume hasil reaksi menjadi berkurang dan yield yang diperoleh kecil.

Tabel 3. Hasil perolehan yield dan perhitungan efek variabel

\begin{tabular}{|c|c|c|c|c|c|c|c|c|c|c|c|}
\hline \multirow[b]{2}{*}{ Perc. } & \multicolumn{3}{|c|}{ Variabel } & \multirow[b]{2}{*}{$\begin{array}{c}\text { Yield } \\
(\%)\end{array}$} & \multicolumn{3}{|c|}{ Efek Tunggal } & \multicolumn{4}{|c|}{ Efek Interaksi } \\
\hline & $\begin{array}{l}\text { Suhu } \\
\left({ }^{\circ} \mathrm{C}\right)\end{array}$ & $\begin{array}{l}\text { Waktu } \\
\text { (Menit) }\end{array}$ & $\begin{array}{c}\text { Rasio } \\
\text { Metanol: } \\
\text { Minyak }\end{array}$ & & $\begin{array}{c}\mathrm{T} \\
\text { (Suhu) }\end{array}$ & $\begin{array}{c}\mathrm{t} \\
\text { (Waktu) }\end{array}$ & $\begin{array}{c}\mathrm{R} \\
\text { (Rasio) }\end{array}$ & $\mathrm{Tt}$ & TR & $\mathrm{tR}$ & TtR \\
\hline 1 & 35 & 30 & $6: 1$ & 53,36 & $-53,36$ & $-53,36$ & $-53,36$ & 53,36 & 53,36 & 53,36 & $-53,36$ \\
\hline 2 & 65 & 30 & $6: 1$ & 55,24 & $+55,24$ & $-55,24$ & $-55,24$ & $-55,24$ & $-55,24$ & 55,24 & 55,24 \\
\hline 3 & 35 & 120 & $6: 1$ & 64,61 & $-64,61$ & $+64,61$ & $-64,61$ & $-64,61$ & 64,61 & $-64,61$ & 64,61 \\
\hline 4 & 65 & 120 & $6: 1$ & 53,15 & $+53,15$ & $+53,15$ & $-53,15$ & 53,15 & $-53,15$ & $-53,15$ & $-53,15$ \\
\hline 5 & 35 & 30 & $15: 1$ & 49,10 & $-49,10$ & $-49,10$ & $+49,10$ & 49,10 & $-49,10$ & $-49,10$ & 49,10 \\
\hline 6 & 65 & 30 & $15: 1$ & 51,42 & $+51,42$ & $-51,42$ & $+51,42$ & $-51,42$ & 51,42 & $-51,42$ & $-51,42$ \\
\hline 7 & 35 & 120 & $15: 1$ & 77,75 & $-77,75$ & $+77,75$ & $+77,75$ & $-77,75$ & $-77,75$ & 77,75 & $-77,75$ \\
\hline 8 & 65 & 120 & $15: 1$ & 54,42 & $+54,42$ & $+54,42$ & $+54,42$ & 54,42 & 54,42 & 54,42 & 54,42 \\
\hline & & & & & $-30,59$ & 40,8 & 6,32 & $-38,99$ & $-11,43$ & 22,49 & $-12,31$ \\
\hline
\end{tabular}




\section{Teknik, 35 (1), 2014, 46}

Pada penelitiannya, Sumangat dan Hidayat (2008) juga melaporkan bahwa karakteristik metil ester terbaik dihasilkan pada proses transesterifikasi dengan suhu $30{ }^{\circ} \mathrm{C}$. Adapun Foidl dkk., (1996) melaporkan bahwa reaksi transesterifikasi minyak jarak pagar dapat dilakukan pada suhu $30{ }^{\circ} \mathrm{C}$ dan menghasilkan biodiesel dengan kadar metil ester $99,6 \%$

Tabel 4. Pengaruh suhu terhadap yield

\begin{tabular}{|c|c|c|c|c|c|c|}
\hline \multirow{2}{*}{ Poin } & \multicolumn{3}{|c|}{ Variabel } & \multirow{2}{*}{$\begin{array}{c}\text { Yield } \\
(\%)\end{array}$} & \multirow{2}{*}{$\Delta$ Yield } & \multirow{2}{*}{ Ket } \\
\hline & $\mathrm{T}$ & $\mathrm{t}$ & $\mathrm{R}$ & & & \\
\hline \multirow[t]{2}{*}{1} & 35 & 30 & $6: 1$ & 53,36 & $1,88 \%$ & $\uparrow$ \\
\hline & 65 & 30 & $6: 1$ & 55,24 & & \\
\hline \multirow[t]{2}{*}{2} & 35 & 120 & $6: 1$ & 64,61 & $11,46 \%$ & $\downarrow$ \\
\hline & 65 & 120 & $6: 1$ & 53,15 & & \\
\hline \multirow[t]{2}{*}{3} & 35 & 30 & $15: 1$ & 49,10 & $2,32 \%$ & $\uparrow$ \\
\hline & 65 & 30 & 15:1 & 51,42 & & \\
\hline \multirow[t]{2}{*}{4} & 35 & 120 & $15: 1$ & 77,75 & $23,33 \%$ & $\downarrow$ \\
\hline & 65 & 120 & $15: 1$ & 54,42 & & \\
\hline
\end{tabular}

\section{Pengaruh Rasio Metanol-Minyak}

Perbandingan metanol-minyak pada percobaan ini dilakukan pada rasio 6:1 dan 15:1. Sesuai dengan Tabel 5, penambahan perbandingan metanol-minyak dari 6:1 menjadi 15:1 menghasilkan fenomena yield yang berbeda.

Tabel 5. Pengaruh perbandingan metanol-minyak

\begin{tabular}{|c|c|c|c|c|c|c|}
\hline \multirow{2}{*}{ Poin } & \multicolumn{3}{|c|}{ Variabel } & \multirow{2}{*}{$\begin{array}{c}\text { Yield } \\
(\%)\end{array}$} & \multirow{2}{*}{$\Delta$ Yield } & \multirow{2}{*}{ Ket } \\
\hline & $\mathrm{T}$ & $\mathrm{t}$ & $\mathrm{R}$ & & & \\
\hline \multirow[t]{2}{*}{5} & 35 & 30 & $6: 1$ & 53,36 & $4,26 \%$ & $\downarrow$ \\
\hline & 35 & 30 & $15: 1$ & 49,10 & & \\
\hline \multirow[t]{2}{*}{6} & 65 & 30 & $6: 1$ & 55,24 & $3,82 \%$ & $\downarrow$ \\
\hline & 65 & 30 & $15: 1$ & 51,42 & & \\
\hline \multirow[t]{2}{*}{7} & 35 & 120 & $6: 1$ & 64,61 & $13,14 \%$ & $\uparrow$ \\
\hline & 35 & 120 & $15: 1$ & 77,75 & & \\
\hline \multirow[t]{2}{*}{8} & 65 & 120 & $6: 1$ & 53,15 & $1,27 \%$ & $\uparrow$ \\
\hline & 65 & 120 & $15: 1$ & 54,42 & & \\
\hline
\end{tabular}

Secara stoikiometri, metanol sebanyak $3 \mathrm{~mol}$ dibanding dengan minyak, sudah cukup untuk membentuk 3 mol metil ester dan 1 mol gliserol. Namun, perbandingan metanol dibuat berlebih bertujuan untuk mengarahkan kesetimbangan reaksi bergeser ke kanan (Prinsip Le Chatelier). Hal itu juga bertujuan untuk meyakinkan terjadinya konversi tinggi dari trigliserida menjadi metil ester. Hal ini ditunjukkan oleh peningkatan yield yang terjadi pada poin 8 dan secara signifikan yield meningkat pada poin 7 (Handayani dkk., 2013).

Namun, penambahan rasio metanol terhadap minyak juga dapat menurunkan yield reaksi. Hal ini disebabkan metanol yang berlebihan melarutkan gliserol yang konsentrasinya semakin meningkat. Akibatnya metanol yang bereaksi dengan trigliserida untuk membentuk metil ester semakin berkurang. Melarutnya metanol dengan gliserol ini menyebabkan terbentuknya emulsi yang harus dipisahkan saat proses pemisahan, sehingga mengurangi yield dihasilkan
(Yoeswono, 2006; Encinar dkk., 2002). Peristiwa ini terjadi pada poin 5 dan 6 Tabel 5 .

\section{Pengaruh Waktu}

Tabel 3 menunjukkan bahwa variabel yang paling berpengaruh adalah variabel waktu, sedangkan Tabel 6 menunjukkan fenomena pengaruh perubahan level waktu tiap poin terhadap yieldnya.

Tabel 6. Pengaruh waktu terhadap yield

\begin{tabular}{|c|c|c|c|c|c|c|}
\hline \multirow{2}{*}{ Poin } & \multicolumn{3}{|c|}{ Variabel } & \multirow{2}{*}{$\begin{array}{c}\text { Yield } \\
(\%)\end{array}$} & \multirow{2}{*}{$\Delta$ Yield } & \multirow{2}{*}{ Ket } \\
\hline & $\mathrm{T}$ & $\mathrm{t}$ & $\mathrm{R}$ & & & \\
\hline \multirow[t]{2}{*}{9} & 35 & 30 & $6: 1$ & 53,36 & $11,25 \%$ & $\uparrow$ \\
\hline & 35 & 120 & $6: 1$ & 64,61 & & \\
\hline \multirow[t]{2}{*}{10} & 65 & 30 & $6: 1$ & 55,24 & $2,09 \%$ & $\downarrow$ \\
\hline & 65 & 120 & $6: 1$ & 53,15 & & \\
\hline \multirow[t]{2}{*}{11} & 35 & 30 & $15: 1$ & 49,10 & $28,65 \%$ & $\uparrow$ \\
\hline & 35 & 120 & $15: 1$ & 77,75 & & \\
\hline \multirow[t]{2}{*}{12} & 65 & 30 & $15: 1$ & 51,42 & $3,00 \%$ & $\uparrow$ \\
\hline & 65 & 120 & $15: 1$ & 54,42 & & \\
\hline
\end{tabular}

Secara umum, yield mengalami kenaikan ketika waktu ditambah dari 30 menit ke 120 menit pada poin 9 , 11, dan 12 meskipun terjadi penurunan pada poin 10. Pada poin ke 9 dan ke 11 terjadi kenaikan yield yang sangat tinggi yaitu sebesar $11,25 \%$ dan $28,65 \%$. Hal ini merupakan alasan yang mendukung hasil perhitungan efek pada Tabel 3 . bahwa pengaruh waktu memberikan nilai yang paling besar $(40,8)$ dibandingkan nilai pengaruh variabel yang lain. Dengan demikian, dapat disimpulkan bahwa waktu merupakan variabel paling berpengaruh dibandingkan dengan variabel suhu dan rasio metanolminyak.

Ong dkk. (2013) secara jelas melaporkan bahwa kontak antara metanol dan minyak akan lebih lama seiring bertambahnya waktu reaksi sehingga akan mengkonversikan lebih banyak metil ester. Freedman dkk., (1984) menyampaikan bahwa penambahan waktu reaksi menyebabkan konversi meningkat. Pada permulaan, reaksi berlangsung lambat karena pencampuran dan dispersi alkohol ke dalam minyak. Secara normal, yield mencapai maksimum pada waktu reaksi kurang dari 90 menit (Leung dan Guo, 2006). Hal tersebut sesuai dalam penelitian yang menggunakan waktu reaksi 30-120 menit yang dibagi menjadi 2 tahap, atau sekitar 15-60 menit tiap tahapnya.

\subsection{Optimasi Variabel Waktu}

Berdasarkan Tabel 3, efek yang paling berpengaruh diantara ketiga variabel adalah waktu. Sehingga untuk mengoptimasi variabel, variabel waktu perlu divariasikan. Sementara dua variabel yang lain dibuat tetap. Suhu yang digunakan adalah $35{ }^{\circ} \mathrm{C}$, sedangkan rasio pereaktan 15:1 dan waktu divariasikan dari 30 menit hingga 120 menit dengan rentang waktu 15 menit tiap percobaannya. Pemilihan besaran variabel tetap suhu dan rasio pereaktan 


\section{Teknik, 35 (1), 2014, 47}

didasarkan pada perolehan yield terbesar $77,75 \%$ (Percobaan 7, Tabel 3).

Jika dilihat dari sebaran titik dalam Gambar 1, maka dapat dijelaskan bahwa kenaikan yield terhadap penambahan waktu tidak berubah secara signifikan, hanya pada waktu 75 menit ke waktu 90 menit terjadi kenaikan yield yang cukup signifikan.

Gambar 1. juga menunjukkan waktu optimal dalam perolehan yield yang didapat, yaitu pada waktu 105 menit dimana perolehan yield sebesar 77,39\%. Pada waktu 120 menit memang diperoleh yield yang lebih besar daripada waktu 105 menit, tetapi perbedaan antara keduanya tidak terlalu signifikan ( $\mathrm{D}$ yield $=0,36 \%$ ), sehingga dalam pembuatannya, untuk memperoleh yield yang hampir sama tidak perlu menggunakan waktu yang lebih lama.

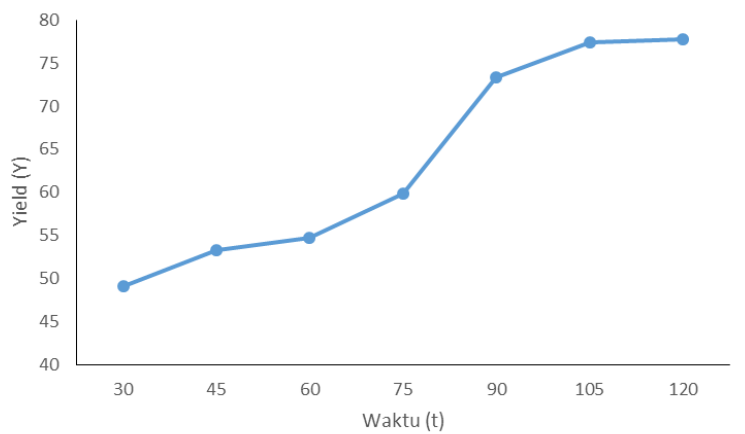

Gambar 1. Grafik hubungan variasi waktu (t) dengan yield (y)

\subsection{Kualitas Produk yang Dihasilkan}

Produk biodiesel minyak biji randu melalui transesterifikasi dua tahap dari kondisi paling optimal suhu $35^{\circ} \mathrm{C}$, rasio metanol-minyak 15:1, dan waktu 105 menit telah diuji sifat fisika-kimianya. Hasil uji laboratorium produk biodiesel minyak biji randu dari penelitian ini disajikan pada Tabel 7.

Tabel 7. Spesifikasi biodiesel minyak biji randu yang dihasilkan

\begin{tabular}{clcc}
\hline No & \multicolumn{1}{c}{ Parameter } & Hasil Uji & $\begin{array}{c}\text { Standar } \\
\text { SNI }\end{array}$ \\
\hline $\mathbf{1}$ & $\begin{array}{l}\text { Massa jenis pada } 40^{\circ} \mathrm{C} \\
\left(\mathrm{kg} / \mathrm{m}^{3}\right)\end{array}$ & 846,97 & $850-890$ \\
$\mathbf{2}$ & $\begin{array}{l}\text { Viskositas kinematik pada } \\
\text { 40 }\end{array}$ & 2,74 & $2,3-6,0$ \\
$\mathbf{3}$ & Angka setana & & min 51 \\
$\mathbf{4}$ & Titik kabut $(\mathrm{mg} \mathrm{KOH} / \mathrm{g})$ & 85,32 & maks 18 \\
$\mathbf{5}$ & Angka asam $(\mathrm{mg} \mathrm{KOH} / \mathrm{g})$ & 2,78 & maks 0,8 \\
$\mathbf{6}$ & Angka iodium $\left(\mathrm{g} \mathrm{I}_{2} / 100 \mathrm{~g}\right)$ & 11,53 & maks 115 \\
$\mathbf{7}$ & Kadar alkil ester $(\% \mathrm{massa})$ & 94,71 & min 96,5 \\
\hline
\end{tabular}

Dari data hasil uji laboratorium pada Tabel 7 menunjukkan bahwa 4 dari 7 parameter yang diuji kelayakannya sebagai bahan bakar mesin diesel telah memenuhi syarat menurut ketentuan SNI 04-71822006, diantaranya viskositas kinematik, angka setana, titik kabut, dan angka iodium. Adapun masa jenis biodiesel yang belum memenuhi ketentuan SNI dikarenakan pemurnian biodiesel yang belum sempurna sehingga perlu adanya kajian lebih lanjut kaitannya dengan pemurnian biodiesel yang kurang sempurna. Tingginya angka asam dikarenakan lamanya penyimpanan produk sehingga alkil ester teroksidasi menjadi asam lemak bebas dan menyebabkan kadar alkil ester yang dihasilkan lebih kecil dari ketentuan yang ditetapkan SNI.

\section{Kesimpulan}

Minyak biji randu dapat dikonversi menjadi biodiesel melalui proses transesterifikasi dua tahap. Dari variabel, suhu, waktu, dan rasio metanol-minyak, Waktu reaksi merupakan variabel yang paling berpengaruh pada reaksi transesterifikasi. Dan untuk menghasilkan biodiesel sesuai dengan standar SNI, reaksi transesterifikasi dilakukan pada Suhu $35{ }^{\circ} \mathrm{C}$, Waktu 105 menit dan Rasio Metanol-Minyak 15:1

\section{Ucapan Terima Kasih}

Terima kasih disampaikan kepada Direktorat Jenderal Pendidikan Tinggi (Dikti) telah mendanai keberlangsungan penelitian ini.

\section{Daftar Pustaka}

$$
\text { (2011). Kapuk Randu. }
$$
http://www.pasuruankab.go.id/potensi-14kapuk-randu.html. Diakses tanggal 19 maret 2013

Ana, S. (2006) Biodiesel Jarak Pagar: Bahan Bakar Alternatif yang Ramah Lingkungan. Jakarta: Agro Media Pustaka

Darnoko, D. dan M. Cheryan. (2000). Kinetics of palm oil transesterification in batch reactor. $\mathrm{J}$. Am. Oil Chem. Soc. 77:1263-1237.

Dewajani, Heny. (2008). Potensi Minyak Biji Randu (Ceiba pentandra) sebagai Alternatif Bahan Baku Biodiesel. Laboratiorium Satuan Operasi Skala Kecil Jurusan Teknik Kimia Politeknik Negeri Malang

Dmytryshyn, S.L., A.K. Dalai, S.T. Chaudari, H.K. Mishra and M.J. Reaney. (2004). Synthesis and characterization of vegetable oil derived esters: Evaluation of their diesel additive properties. Bioresource Technology 92:55-64.

Dorado., M.P., E. Ballesteros, J.A. De Almeida, C. Schellert, H.P. Lohrlei $\mathrm{n}$ and R. Krause. (2002). An alkali -caalyzed transesterification process for high free fatty acid waste oils. Transaction of American Society of Agricultural Engineers 45(3): 525-529.

Encinar, J. M., Gonzales, J.F., Rodriguez, J.J., Tejedor, A., (2002). Biodiesel Fuels from Vegetable Oils : Transesterefication of Cynara cardunlus L. Oils with Ethanol. Energy \& Fuels. J.A.C.S.,16

Erricson, D. R. 1990. Edible Fats and Oils Processing: Basic Principles and Modern Practices : World Conference Proceedings (Book style with paper title dan editor). The American Oil Chemists Society. 124-126. 


\section{Teknik, 35 (1), 2014, 48}

Foidl, N., G. Foidl, M. Sanchez, M. Mittelbach, and S. Hackle. (1996). Jatropha curcas for biodiesel production in Nicaragua. Bioresouce Technology 58(1): 77-82.

Freedman B, Pryde EH, Mounts TL. (1984). Variables affecting the yields of fatty esters from transesterified vegetable oils. J Am Oil Chem Soc. 61: 1638-43.

H. Soerawidjaja, Tatang. (2005). Membangun Industri Biodiesel di Indonesia 'Beberapa Skenario dan Persoalan Pengembangan yang Perlu Dicermati. Forum Biodiesel Indonesia (FBI). Bandung

Hambali, Erliza. (2006). Diversifikasi Produk Olahan Jarak Pagar dan Kaitannya dengan Corporate Social Responsibility (CSR) Perusahaan Swasta di Indonesia. Eka Tjipta Foundation. Bogor

Handayani, N.A., Santosa, H., Sofyan, M., Tanjung, I., Chyntia, A., P. Asih R.S.P., \& Ramadhan, Z.R. (2013). Biodiesel Production from Kapok (Ceiba Pentandra) Seed Oil using Naturally Alkaline Catalyst as an Effort of Green Energy and Technology. Int. Journal of Renewable Energy Development, 2(3),169-173.

Khan, A. K. (2002). Research Into Biodiesel Kinetics and Development. The University of Queensland, Queensland.

Knothe, G., Van Gerpen, J. H. and Krahl, J. (2005). The Biodiesel Handbook, AOCS Press, Champaign, III.

Lang, X., A.K. Dalai, N.N. Bakhshi, M.J. Reaney and P.B. Hertz. (2001). Preparation and characterization of bio-diesels from various bio-oils. Bioresouce Technology 80: 77-82.

Leung DYC, Guo Y. (2006). Transesterification of neat and used frying oil: optimization for biodiesel production. Fuel Process Technol; 87:883-90.

Marchetti, J.M. and Errazu, A.F. (2008). Comparisson Of Different Heterogeneous Catalysts And
Different Alcohols For The Estherification Reaction Of Oleic Acid. Fuel, 87. 3477-3480

Noureddini, H. dan D.Zhu. (1997). Kinetics of transesterification of soybean oil. J. Am. Oil Chem. Soc.74:1457-1463.

Ong, H.C., Silitonga, A.S., Masjuki, H.H., Mahlia, T.M.I., Chong, W.T., Boosroh, M.H. (2013). Production and comparative fuel properties of biodiesel from non-edible oils :Jatropha curcas, Sterculia foetida, and Ceiba pentandra. Energy conversion and management, 73, 245-255

Prihandana, Rama dan Hendroko, Roy, Nuramin, Makmuri. (2006). Menghasilkan Biodiesel Murah : Mengatasi Polusi \& Kelangkaan BBM. PT Agro Media Pustaka. Jakarta.

Santoso, N., F. Pradana, dan Rachimoellah. (2012). Pembuatan Biodiesel dari Minyak Biji Kapuk randu (Ceiba pentandra) Melalui Proses Transesterifikasi dengan Menggunakan $\mathrm{CaO}$ sebagai Katalis. Jurusan Teknik Kimia, Fakultas Teknologi Industri, Institut Teknologi Sepuluh November (ITS)

Sumangat, D. dan Hidayat, T. (2008). Karakterisasi Metil Ester Minyak Jarak Pagar Hasil Proses Transesterifikasi Satu dan Dua Tahap. J.Pascapanen: Balai Besar Penelitian dan Pengembangan Pascapanen Pertanian

Susilowati. (2006). Biodiesel dari Minyak Biji Kapuk dengan Katalis Zeolit. Jurusan Teknik Kimia Fakultas Teknologi Industri UPN "Veteran". Jatim.

Widyawati, Y. (2007). Disain Proses Dua Tahap Esterifikasi-Transesterifikasi (Estrans) Pada Pembuatan Metil Ester (Biodiesel) Dari Minyak Jarak Pagar (Jatropha Curcas.L). Sekolah Pascasarjana Institut Pertanian Bogor.

Yoeswono, J. sibarani, dan S. Khairi. (2006). Pemanfaatan Abu Tandan Kosong Kelapa Sawit sebagai Katalis Basa pada Reaksi Transesterifikasi dalam Pembuatan Biodiesel. Jurusan Kimia Fakultas MIPA Universitas Gadjah Mada, Yogyakarta. 